\title{
LITERATUROZNAWSTWO
}

Jadwiga Gracla

DOI $10.15290 / \mathrm{sw} .2018 .18 .01$

Uniwersytet Warszawski

Wydział Lingwistyki Stosowanej

Katedra Białorutenistyki

tel. +48 225534254

e-mail: j.gracla@uw.edu.pl

ORCID ID: https://orcid.org/0000-0002-8142-2867

\section{Modernistyczne dialogi ze śmiercią. Kulturowe inkarnacje i personifikacje}

Słowa kluczowe: śmierć, postać, dramat, modernizm, wyobrażenie

Śmierć jako motyw literacki nie jest obca literaturze żadnej epoki. Przemijanie, kres, nieubłagane przybliżanie się do chwili zakończenia ziemskiej egzystencji, a także postawy, zajmowane wobec śmierci, przemyślenia, strach, nadzieja jej towarzyszące, $\mathrm{z}$ różnym natężeniem i akcentem funkcjonują w utworach literackich należących do wielu epok, kierunków i kultur. W literaturze modernizmu (rozumianego w szeroki sposób) temat ten przeplata się z charakterystycznymi dla poszczególnych kierunków epoki motywami kresu świata, fin de scieclu, rozpadu, rozkładu, zepsucia i gnicia (typowymi dla dekadentyzmu), poszukiwaniem mglistych dali i nowych mistycznych przestrzeni (obserwowanymi w tekstach symbolistów), czy też kreowaniem nowych światów powstających na gruzach usuniętego porządku (futuryści). W tekstach dramaturgicznych epoki modernizmu, szczególnie interesujących w kontekście tematu, odnaleźć można jednak jeszcze inny ślad obecności tego motywu. Są nim nawiązania do średniowiecznych misteriów, rozmów ze Śmiercią, dance macabre (Corvisier, 1998) nierzadko wraz z przynależnym mu anturażem i wizerunkiem. Najłatwiej odnaleźć je w tytułach powstających dramatów: Taniec śmierci pojawi się w sztukach Augusta Strindberga (Dodsdansen, 1900), Franka Wedekinda (Todentanz, 1905, późniejszy tytuł: Tod und Teufel Diabet 
i śmierć - JG) czy Hansa Jahnna i Wernera Helwiga (Neuer Lübecker Todestanz 1931, Nowy lubecki taniec śmierci - JG) czy Oedona von Horvatha (Glaube. Liebe. Hoffnung. Ein Todestanz, 1932, Wiara. Miłość. Nadzieja. Taniec śmierci - JG). Teksty te jednakże, mimo obecnego w tytule nawiązania do średniowiecznego korowodu prowadzonego przez uosobienie Śmierci - kościotrupa, nie są kolejnym wariantem tego obrazu (zachowującym przerażającą symbolikę), a raczej refleksją o nieuchronnym koń$\mathrm{cu}$, nieco biologicznym, naturalistycznym ujęciem znanego tematu. Istnieją jednak i takie teksty, w których Śmierć pojawia się jako pełnoprawna postać dramatu - inkarnacja zjawiska - a co za tym idzie przeksztalca się ona $\mathrm{w}$ nich $\mathrm{w}$ uczestnika dialogu, przywodząc na myśl średniowieczne rozmowy ze śmiercią. Z taką sytuacją spotkać się można w przypadku sztuk Hugona von Hofmannstahla Błazen i Śmierć (Der Tor und der Tod, 1893) Wielki Salzburski teatr świata (Das Salzburger große Welttheater, 1919-1922) (Boltenauer von), Sigizmunda Krżyżanowskiego Śmierć rzuca kości (Смерть бросает кости, 1930), Wielimira (Wielemira, właściwie Wiktora) Chlebnikowa Bład śmierci (Oшибка Смертu, 1915), Witolda Wandurskiego Śmierć na gruszy $(1923)^{1}$, czy też w filmie Fritza Langa z 1921 roku Zmęczona śmierć (Der müde Tod. Das deutsche Volkslied in sechs Versen).

W przywołanych tu utworach śmierć pojawi się nie jako zapowiedź nieuchronnego końca, zjawisko egzystencjalne, nieuchwytna chwila kończąca ziemską wędrówkę, ale jako pełnoprawna postać osoba dramatu (tekstu filmowego). I to właśnie wydaje się najciekawszym chwytem. Bowiem o śmierci napisano już wiele, jednak pojawienie się jej jako postaci pozwala na jeszcze inne spojrzenie. Personifikowanie śmierci, nadanie jej w pewnym sensie ludzkiego kształtu (w niektórych z przywołanych utworów pojawia się ona jako szkielet ubrany w czarną opończę) pozwala nie tylko na rozpoczęcie z nią dialogu, ale przede wszystkim na pozbawienie jej na chwilę najbardziej przerażających atrybutów. Śmierć (Ohler, 2003), Thanatos, Śmiertka, Kostucha, Kosiarz zaludniają wyobraźnię człowieka i jednocześnie - nadając jej zrozumiałą i podobną do adwersarza formę - pozwalają mu na

1 Tekst ten na szczęście nie został zupełnie zapomniany. W 20016 roku odbyla sie jego kolejna realizacja sceniczna w łódzkim teatrze. Autorzy realizacji tak o nim mówili: ŚMIERĆ NA GRUSZY dramat Witolda Wandurskiego stanowi przykład nowatorskiego tekstu w formie ludowej i religijnej przypowieści napisanego dla awangardowej formacji teatralnej jaką był teatr robotniczy czyli projekt sceniczny Wandurskiego skierowany do konkretnego widza. Jednak ŚMIERĆ NA GRUSZY może stać się tekstem wychodzaccym daleko poza perspektywy z jakich został pomyślany i uwarunkowania $\mathrm{w}$ jakich został napisany. http://www.teatr-jaracza.lodz.pl/smierc.html 
próbę oszustwa, zmierzenie się z nią i trwające tylko mgnienie pozbawienie mocy.

Wydaje się, że najsłabiej przekształcona, w stosunku do średniowiecznych wyobrażeń, jest śmierć przedstawiona w dramacie Hofmannstahla Wielki Salzburski teatr świata. Postać, która się tam pojawia, wyposażona w typowe atrybuty - kosę, czarną opończę, czaszkę, staje się jedynie wykonawcą woli Boga. Podjęcie z nią dialogu, zakładającego wymianę argumentów, próbę przekonania czy oszukania nie jest możliwe. Doświadcza tego Rolnik, który nie chce poddać się wołaniu Śmierci, początkowo tłumacząc jej, że ma jeszcze do skończenia pracę w polu. Kiedy ta perswazja nie pomaga, udaje, że jej nie słyszy, później stara się uciec do lasu. Wszystkie te próby oczywiście skazane są na niepowodzenie, Śmierć nieubłaganie woła go do siebie, i mimo próśb i tłumaczeń, zabiera ze sobą. Specyficzny dialog - w formie wymiany komunikatów nie refleksji i argumentów jaki pojawi się w dramacie Hofmannstahla, podkreśla władzę śmierci, niemożność ucieczki przed nią. Jednak Śmierć nie jest tu przedstawiona jako postać budząca grozę, nikt na jej widok nie ucieka z krzykiem, nie chowa się w popłochu. Strach i pretensje budzi raczej przesłanie, jakie ze sobą przynosi, tym samym więc sama Śmierć przestaje być postacią przerażającą. Tym bardziej, że, jak dowodzą początkowe sceny dramatu, jest ona jedynie wykonawcą woli Boga, ma więc do spełnienia pewną konkretną dramaturgiczną rolę, podobnie jak pozostałe osoby dramatu². Nie może się przeciwko owemu działaniu zbuntować, wykonuje przeznaczone czynności jak trybik w wielkiej maszynie wszechświata. Chwyt ten sprowadza ją do poziomu postaci sztuki, odgrywających swoją rolę, w kształcie nadanym im przez Boga wydobywającego bezkształtną duszę i po nadaniu jej formy wysyłającego ją na ziemię. Spotkanie z nią zakłada brak możliwości dyskusji, ale nie jest momentem sądu, który dopiero ma nastąpić. Odarta z tego aspektu - wymierzania sankcji - przestaje przerażać piekielnymi mękami i kara za grzechy. Śmierć zabiera człowieka ze świata (nie prowadzi go jednak do piekieł), staje się jego towarzyszem w wędrówce powrotnej, do miejsca przebywania dusz, jedynym pewnikiem w nieznanej, zapomnianej drodze.

Ten aspekt pewnej łagodności, dobroci Śmierci-przewodnika podkreślił Hofmannstahl w swoim dramacie lirycznym Błazen i śmierć. Inaczej niż w przypadku poprzedniego utworu pojawia się tu rzeczywisty dialog

2 Początkowe sceny dramatu przedstawiaja proces kształtowania i wysyłania dusz na ziemię. W jego trakcie każdej duszy zostaje przeznaczona określona rola, która będzie jej udziałem na ziemi. 
ze Śmiercią. Claudio, tytułowy bohater, spotyka ją w swoim ogrodzie, zwabiony piękną melodią skrzypiec. Zamiast kosy, czaszki i szkieletu przed jego oczami pojawia się postać ze skrzypcami, która tłumaczy mu nie tylko zawiłości życia, ale również nieuchronność śmierci, kresu, końca. Nie przybywa sama - wraz z nią przed Claudiem stają jego matka i kobieta, którą kiedyś skrzywdził. To ona prosiła o możliwość towarzyszenia bohaterowi w ostatniej godzinie, by go wesprzeć i pomóc. Śmierć, przybywająca po głównego bohatera, świadoma swojej roli, mówi przecież: „Moje przybycie zwiastuje tylko jedno" (Hofmannstahl H. Von), przestaje być straszna, a wręcz przeciwnie, jest łagodna, współczująca, delikatna. Sprzyja temu towarzyszący jej rekwizyt: zamiast kosy dzierży skrzypce i na nich wygrywa piękną melodię. Wabi ku sobie, niczym mityczny śpiew syren, pozwalając kroczyć za sobą z własnej woli. Podążające za nią postacie: Matki, Kobiety, na końcu zaś Claudia pozornie tworzą korowód śmierci, wracają więc do średniowiecznego obrazu dance macabre. Niemniej jednak Śmierć z dramatu Hofmannstahla nie budzi makabrycznych, widmowych, niesamowitych skojarzeń. Jest wysłannikiem, przewodnikiem do innego świata, który przestaje być przerażający. Jest raczej krainą, gdzie spotkamy tych, których kochaliśmy, którzy odeszli, którzy nam wybaczyli. Śmierć prowadzi do Arkadii, nie na sąd i nie do piekieł. Tłumacząc sens życia, choć u jego kresu, wyjaśnia przyczyny swojego przybycia i pokazuje jednocześnie, że wraz z nią nic, mimo obaw Claudia, się nie kończy. Wydaje się nawet, że bohater podąża za nią dobrowolnie, nie tylko wiedziony melodią skrzypiec, ale przekonany o słuszności swojego wyboru i pogodzony z kresem ziemskiej egzystencji.

Inaczej przedstawiają śmierć pisarze transformujący obrazy wierzeń ludowych. Zachowując świadomość jej nieuchronności, jednocześnie próbują ją oszukać, sprawiając, że staje się ona istotą równorzędną wobec postaci dramatu, podatną na oszustwa i obdarzoną cechami ludzkimi. Jednocześnie jednak zachowują utrwalony w powszechnej wyobraźni wizerunek: Śmierć w przywołanych tekstach przybywa w postaci kościotrupa, okrytego czarną opończą z lampką (latarnią), pochodnią lub kosą w ręce. Można ją jednak oszukać, sprawić, by jej moc ustała, uwięzić, zmusić do błędu. Taka śmierć pojawia się w dramatach: Śmierć rzuca kości, Bład śmierci, Śmierć na gruszy. W wszystkich tych utworach wykreowany obraz śmierci jest zgodny ze średniowiecznymi wyobrażeniami, ludowymi obrazami: kościotrupa z kosą i zgaszoną pochodnią. Taka właśnie zaistnieje przed oczami odbior-

3 W języku niemieckim śmierć jest rzeczownikiem rodzaju męskiego. W tekście posługuję się formą żeńską, wynikającą z reguł języka polskiego. 
cy w tekście Krżyżanowskiego Śmierć rzuca kości. Wypada tu zauważyć, że autor sztuki nadał jej specyficzną, choć dla początku XX wieku dość charakterystyczną formę pantomimy ${ }^{4}$, przygotowując ją niejako do scenicznej realizacji ${ }^{5}$. Wykreowana przez Krżyżanowskiego opowieść transformuje image śmierci, odziera ją z jakiegokolwiek patosu, a co więcej niweczy również wszelkie przerażające atrybuty. Dzieje się tak mimo zachowania znanego z tradycji anturażu postaci. Ubrana w otulającą szkielet czarną opończę Śmierć z czerwoną latarnią w dłoni przybywa do miasteczka. Zastaje opustoszałe ulice i zamknięte, zabezpieczone białymi krzyżami okiennice. Nie znalazłszy innej ofiary, dostrzega Brzozka i jego narzeczoną Magdę. Wydawać by się mogło, że w tym momencie dramaturg rysuje przed oczami odbiorcy scenę wręcz idylliczną: oświadczyny, ich pierwszy pocałunek. Jednak nie pojawia się tu najbardziej oczywisty symbol dobra i prognostyk szczęścia, scena nie rozjaśnia się tysiącem płomieni świec, nie skrzy promieniami słońca. Świeczka, która stała w oknie Magdy, przewraca się i gaśnie. Sytuacja ta odwołuje się nie tylko do najbardziej archetypicznych wyobrażeń dobra i zła, ale również do czytelnego symbolu ludzkiego życia: palącej się i gasnącej świecy. Nieco później Brzozek spotyka Śmierć w knajpie. I rozpoczyna dialog, spór, grę - początkową zabawną, później przepełnioną pijackim animuszem i przechwałkami. Właśnie w trakcie gry przeciwko latarni Śmierci rzuca na stół portret ukochanej, pieczętując tym samym jej los. Być może jest to jeden z wariantów najbardziej znanej sytuacji: zamiany i ofiary, wykorzystanej również w filmie Zmęczona śmierć - za zabierane przez śmierć życie można oddać inne, jest to jedyny sposób targu. Tymczasem Brzozek zwycięzca pojedynku - wspierany przez pijany i awanturujący się tłum krępuje Śmierć i zamyka ją w klatce. To z kolei wariant znany z Sabałowej opowieści ${ }^{6}$ i wykorzystany również w dramacie Wandurskiego Śmierć na gruszy, gdzie zaciekawiona zawartością dziupli Śmierć zostaje w niej uwięziona. W przypadku dramatu Krżyżanowskiego miejscem uwięzienia będzie klatka w domu Brzozka. Z pozoru szczęśliwe zakończenie staje się początkiem pa-

4 „W XX w. pantomima była obiektem eksperymentów formalnych i artystyczno-intelektualnych, do których zaliczane są: ćwiczenia Jacques'a Copeau, idea mimu czystego i rzeźby ruchomej Etienne'a Decroux, stworzenie przez Decroux i Jeana Louisa Barraulta podstaw techniki pantomimicznej i autonomicznego języka pantomimy, etiudy Marcela Marceau (Bip), który wyznaczył linię jej rozwoju jako solowego popisu mima" cyt. za: http://www.encyklopediateatru.pl/hasla/226/pantomima, data dostępu 10.05.2017. Szerzej na ten temat zob: P. Skrzypczak, Aktor i jego postać ekranowa. Aktorstwo kina niemego w teorii i refleksji krytycznej, Toruń 2009; K. Smużniak, Pantomima XX wieku. Kierunki i tendencje, Zielona Góra 2002.

5 Sztuka jednak nie została wystawiona.

6 Została opisana w: H. Sienkiewicz, Sabałowa bajka, Warszawa 1901. 
sma nieszczęść, gdyż do głównego bohatera przychodzą kolejno: samobójcy i starcy, proszac by choć na chwilę wypuścił Śmierć z klatki. Ten jednak odmawia, napawając się swoją władzą. Scena ta wskazuje na konieczność i potrzebę istnienia kresu, na rolę, jaką Śmierć odgrywa w życiu człowieka. Po raz kolejny więc zostaje ona pozbawiona owej surowości. Wydaje się raczej czymś wyczekiwanym: końcem, wybawieniem, kresem męki. Ale jednocześnie wraz z upływem czasu spędzonego w uwięzieniu staje się coraz bardziej przebiegła, nabiera najgorszych cech człowieka. Śmierć dotychczas (szczególnie w średniowiecznych refleksjach) była jedynie wysłannikiem Boga, wykonawcą jego woli, przekonanym o nieomylności i miłosierdziu swego mocodawcy. Pokonana i upokorzona przez Brzozka, w chwili, w której na noszach wnoszą jego przyjaciela i kiedy sam główny bohater byłby w stanie w ludzkim, przyjacielskim odruchu ją wypuścić, staje się przebiegłym i fałszywym stworzeniem. Przypomina sobie o swojej mocy i mści się okrutnie nie zabiera przyjaciela, lecz Magdę, która uległa jej mocy. W pustej klatce pozostaje jedynie portret narzeczonej, a Śmierć odzyskuje wszystkie zabrane jej rekwizyty: kosę i latarnię, i skazuje Brzozka na życie - nad osłupiałym z rozpaczy mężczyzną jasnym płomieniem pali się niegasnąca pochodnia. Wykreowana w sztuce postać Kostuchy jest więc dokładnym odzwierciedleniem człowieka wraz z jego wadami - i dlatego bohater może początkowo podjąć z nią grę i rozmowę. Ale dlatego też udaje jej się zwyciężyć. Śmierć zabiera, co jej się należy, co sama uznała za swoją własność i czym najbardziej dotknie głównego bohatera. To śmierć-mścicielka, żądna wygranej hazardzistka, nieznająca litości i miłosierdzia. Upokorzona przez Brzoska wymierza mu karę według miary swojej urażonej dumy, a nie swoich zasad. To nie układ życie za życie, lecz kara za upokorzenie. Jeżeli więc Śmierć potrafi się odegrać, staje się podobna do człowieka, nabiera jego najgorszych cech. Przeciwniczka Brzozka jest katem i sędzią jednocześnie, uzurpuje sobie prawo, którego wcześniej nie miała. Ową antropomimetyzację podkreślają uwagi w tekście: „Patrzy na swoje dzieło. Jest zadowolona. Zrobione na czysto" (Кржижановский С. Д.). Czerpie więc ze swojego czynu satysfakcję napawa się swoją zemstą i odchodzi.

Ludzkimi cechami została obdarzona również Pani Śmierć z dramatu Chlebnikaowa - Btad śmierci. I tym razem ulega w pierwszym momencie człowiekowi - Trzynasty gość przybywający na urządzoną przez nią ucztę domaga się jej czaszki jako pucharu. Oślepiona Pani Śmierć wybiera zły napój - ten który niesie wieczną śmierć. Ale po chwili jest gotowa oznajmić, że jej błąd pozbawiony jest konsekwencji. Przekomarzająca się bowiem z Trzynastym gościem Pani Śmierć odgrywa rolę - gospodyni przyjęcia. Przedstawiona w tekście Chlebnikowa postać - w końcowym fragmencie 
szkielet pozbawiony czaszki - staje się z jednej strony świadectwem woli i zdecydowania człowieka, który jest w stanie zmusić śmierć do oddania jednego ze swoich atrybutów, z drugiej strony jest nieco karykaturalnym, śmiesznym obrazem Kostuchy, którą można oszukać. To zbliża ją do wyobrażenia przedstawionego w poprzednim dramacie (Śmierć rzuca kości). Paradoksalnie jednak to też wskazuje na siłę śmierci. Pozornie pokonana, tak jak miało to miejsce w przypadku Śmierci rzucajacej kości w efekcie końcowym okazuje się niepokonana - jakby tylko na moment pozwoliła z siebie zadrwić, świadomie dając swojemu adwersarzowi chwilową satysfakcję. Śmierć z dramatu Chlebnikowa umieszcza człowieka w teatrze: Trzynasty gość, przybywający na ucztę, nieoczekiwany, dla którego nie ma nawet pucharu, zostaje wrzucony w scenę już przygotowaną, odgrywa zapewne nieświadomie przypisaną mu rolę. Jego dialog z Panią Śmierć nacechowany pewnością siebie i poczuciem zwycięstwa jest tylko z góry zapisaną rolą, przeznaczeniem, od którego nie ucieknie, a Śmierć okaże się zwycięzcą swoistego pojedynku. Chwila, w której mówi ona: „dajcie mi Bład Śmierci” (Хлебников) (tekst) sprowadza wszystko do pierwotnego stanu - wszystko bowiem zostało zaplanowane, nawet zapisane, nic nie zależy od człowieka, choć pozornie ma on poczucie samodzielności, swobody decydowania o sobie i możliwości pokonania przeznaczenia. Tymczasem gra ze śmiercią, choć paradoksalnie nazwana jej błędem, jest jedynie pozorem możliwości - zakłada, że Pani Śmierć, podobnie jak człowiek, chce pewnej dozy radości, żartu, ryzyka (scena wyboru pucharu), by za moment powrócić do swojej normalnej postaci.

Podjęcie dialogu ze śmiercią nie prowadzi więc do zmiany przeznaczenia. Ciągle jawi się ona jako niezmienna, nieprzekonana siła. Sceny, w których człowiekowi udaje się pokonać śmierć - nawiązujące nie do biblijnych obrazów, lecz do ludowych podań: od Sabałowej historii po legendę o rozmowie śmierci z Bogiem - wskazują na wolę życia i, co może ważniejsze, przekonanie o możliwościach człowieka i podobieństwie Śmierci do człowieka. Taki obraz śmierci pozwala na chwilę zapomnieć o strachu, daje człowiekowi nadzieję i możliwość spotkania się z nią twarzac w twarz stwarza, choć tylko pozornie, sytuację, w której człowiek może zadecydować o sobie i odsunąć moment kresu. Obraz ten jednocześnie ujawnia inną twarz śmierci. Kostucha pokonana mści się, szuka zemsty za swoje upokorzenie, żartuje z człowieka. Nie jest więc jedynie istotą kładącą kres życiu bez względu na pochodzenie, stan i charakter. Jest siłą, którą można oszukać, ale nie można pokonać. Niemniej jednak choć jeden dzień wyrwany śmierci jest wygraną człowieka i świadectwem tego, że nie jest zupełnie bezbronny w starciu z nią. Podjęcie dialogu z taką Kostuchą jest bowiem możliwe. 


\section{Literatura}

\section{Teksty}

Hofmannstal H. Von, Der Tor und der Tod, [online] http://gutenberg.spiegel.de/ buch/der-tor-und-der-tod-1009/1, [14.01.2018].

Wandurski W., 1968, Śmierć na gruszy, Warszawa.

Kržižanovskij S.D., Smert' brosaet kosti [Кржижановский С.Д., Смерть бросает костu], [online] http://az.lib.ru/k/krzhizhanowskij_s_d/text_1930_smert_bro saet_kosti.shtml [14.01.2018].

Hlebnikov B., Ošibka Smerti [Хлебников B., Oшибка Cмертu], [online] http://rvb. $\mathrm{ru} /$ hlebnikov/mat/contents.htm, [14.01.2018].

Boltenauer von, A., Ästhetik des Sterbens. Der Tod als literarisches Motiv in der Wiener Moderne, [online] http://www-gewi.kfunigraz.ac.at/moderne/heft 4b.htm, data dostępu 14.01.2018.

Corvisier A., 1998, Les danses macabres, Paris: PUF.

Gold A., Aesthetik des Sterbens, w: „Die Zeit” 24.2.1900 (Wien), 121-122.

Ohler N., 2003, Sterben und Tod im Mittelalter, Patmos, Düsseldorf.

Sienkiewicz H., 1901, Sabałowa bajka, Warszawa.

Skrzypczak P., 2009, Aktor i jego postać ekranowa. Aktorstwo kina niemego w teorii $i$ refleksji krytycznej, Torun.

Smużniak K., 2002, Pantomima XX wieku. Kierunki i tendencje, Zielona Góra.

Szturc W., 2015, Dotkliwe przestrzenie: studia o rytmach śmierci, Kraków.

Śmierć w literaturze i kulturze drugiej połowy XIX wieku, 2002, pod red. E. Paczoskiej i U. Kowalczuk, Warszawa.

Wunderlich U., 2001, Der Tanz in den Tod. Totentänze vom Mittelalter bis zur Gegenwart, Eulen, Freiburg/Br.

Ar'es F., 1992, Čelovek pered licom smerti, Moskva. [Арьес Ф., 1992, Человек перед личом смерти, Москва].

DIALOGUES WITH THE DEATH OF MODERNISM.
CULTURAL INCARNATIONS AND PERSONIFICATIONS

S U M M A R Y

The purpose of this article is to show the character of death as a full-fledged hero of a literary work. The author analyzes Hofmannstahl's dramas: The Fool and the Death, Great Salzburg's World Theater, Chlebnikov: Death's Bug, Krzanowski's Death throws bones.

The images of death that appear in them present it as the messenger of God and the companion of the journey to the land of the beginning. In this performance, it loses its scary features. Otherwise, the author uses folk imagery of death. Then it is endowed with human qualities - it can be deceived, though it can not be won with it. 